\title{
Article \\ eWOM in C2C Platforms: Combining IAM and Customer Satisfaction to Examine the Impact on Purchase Intention
}

\author{
Salvador Bueno (1) and M. Dolores Gallego * \\ Department of Management and Marketing, Universidad Pablo de Olavide, 41013 Sevilla, Spain; sbueavi@upo.es \\ * Correspondence: mdgallego@upo.es or mdgalper@upo.es
}

Citation: Bueno, S.; Gallego, M.D. eWOM in C2C Platforms: Combining IAM and Customer Satisfaction to Examine the Impact on Purchase Intention. J. Theor. Appl. Electron. Commer. Res. 2021, 16, 1612-1630. https://doi.org/10.3390/jtaer1605 0091

Academic Editor: Andreja Pucihar

Received: 15 March 2021

Accepted: 13 May 2021

Published: 17 May 2021

Publisher's Note: MDPI stays neutral with regard to jurisdictional claims in published maps and institutional affiliations.

Copyright: (c) 2021 by the authors. Licensee MDPI, Basel, Switzerland. This article is an open access article distributed under the terms and conditions of the Creative Commons Attribution (CC BY) license (https:// creativecommons.org/licenses/by/ $4.0 /)$.

\begin{abstract}
This study is focused on communications that come from consumer-to-consumer (C2C) ecommerce relationships. This topic is directly associated with the electronic word-of-mouth (eWOM) phenomenon. eWOM is related to the set of positive or negative opinions made by potential, actual, or former customers about a seller. The present study proposes a structural equation modeling with partial least squares (PLS-SEM) research model to analyze consumers' opinions impact on attitude toward purchasing. This model is based on the Information Adoption Model (IAM) in combination with an ecommerce satisfaction perspective, comprising five constructs: (1) service quality, (2) ecommerce satisfaction, (3) argument quality, (4) source credibility and (5) purchase intention. The model was tested by applying the Smart Partial Least Squares (SmartPLS) software for which 116 effective data from customers of the Taobao C2C platform were used. The findings reveal that all of the defined relationships were supported, confirming the positive impact of all the proposed constructs on the purchase intention. In this respect, the findings suggest that $\mathrm{C} 2 \mathrm{C}$ platforms should strengthen the analyzed connections to grow the business and to promote transactions. Finally, implications and limitations related to the explanatory capacity and the sample are identified.
\end{abstract}

Keywords: consumer-to-consumer (C2C); Information Adoption Model (IAM); relationships; ecommerce; purchase; electronic word-of-mouth (eWOM); ecommerce satisfaction

\section{Introduction}

In recent years, many consumer-to-consumer (hereafter, $\mathrm{C} 2 \mathrm{C}$ ) ecommerce platforms have emerged [1]. Considering the type of goods, some remarkable examples can be identified, such as Avancar, SocialCar or Blablacar for car-sharing or rental services; Airbnb for accommodations; or Wallapop and Taobao for second-hand goods [2,3], among many others. This phenomenon is also known as collaborative consumption. In fact, some authors have considered it as a reinvention of traditional markets [4], such as bartering or exchange. In this manner, collaborative consumption can now be developed on a global scale thanks to technology [5], promoting the reasonable use of goods [6].

In this context, the success of these platforms is largely determined by the registered opinion of its users [7]. In this sense, consumers frequently make decisions related to purchases only under the influence of opinions exposed by other consumers [8]. In fact, the shopping experience is as important as sharing this shopping experience to influence the purchase process [9]. Thus, this study is associated with the topic of electronic wordof-mouth (eWOM) relationships. In this respect, according to [10], eWOM refers to "any positive or negative statement made by potential, actual, or former customers about a productor company, which is made available to a multitude of people and institutions via the Internet".

In this manner, ref. [11] concluded that it is a platform to obtain trustable and reliability information about goods and services to support decision-making processes regarding purchase intentions. In this respect, according to [12], C2C eWOM can modify customer preferences and behavior toward a specific purchase [13]. Under this premise, consumers 
have become a relevant way for sharing information [14]. Indeed, in C2C purchases, trust is considered one of the crucial determinants for widespread online exchange relationships [15-17].

Therefore, consumers contribute to increasing the value of these platforms by sharing information with other consumers. In fact, $\mathrm{C} 2 \mathrm{C}$ communications play a relevant role in brand and service acceptance [18]. In this manner, C2C ecommerce enables tools to facilitate consumers' opinions to reduce purchasing uncertainties. Indeed, the use of eWOM on social media has helped marketing managers to expand sales [19]. In this line, ref. [14] demonstrated that consumers evaluate a set of trust dimensions for making purchase decisions, considering all the reviews, reviewers and sites that they encounter as they visit the marketspace. Based on [20], trust in an eWOM context has a twofold dimension: (1) cognitive and (2) affective. Consequently, the exchanged information in an eWOM platform is considered to be more trustworthy among consumers because it transmits directly the experiences of users without any barriers [21].

According to [22], it is expected that USD 40.2 billion in sales for online platforms will be reached by 2022. C2C commerce is widely spread in developed countries [23]. In this respect, China is recognized as one of the countries with the highest growth in C2C [24]. Indeed, according to the report entitled Global Digital Report (2018), the number of internet users from China has risen to reach $53 \%$ of the population. In this way, this report included Taobao as third in the ranking of top mobile apps, considering two aspects: (1) monthly active users and (2) number of downloads. Taobao is the leading online platform for C2C trading in China (owned by Alibaba), providing an electronic platform for small business and individuals to carry out online sales. Taobao is exclusively available in the Chinese language and it can be only used by users with a Chinese bank account.

The aim of this study is to analyze how consumer's opinions influence other consumers regarding their attitude toward purchasing, focusing on the C2C platform Taobao. Thus, a structural equation modeling with partial least squares (hereafter, PLS-SEM) model has been proposed based on the Information Adoption Model (hereafter, IAM) developed by [25], adopting an ecommerce satisfaction perspective. The IAM framework has been widely used in research for different contexts to explain how individuals adopt and process persuasive information in communication platforms. IAM has a dual origin. On the one hand, this theoretical framework is based on Technology Acceptance Model (TAM), proposed by [26], and, on the other hand, on the Elaboration Likelihood Model (ELM) to incorporate aspects related to message persuasiveness. In fact, ELM explains how people are influenced by received messages in persuasive communication [27]. In particular, the impact of registered consumers' opinions and scores in a C2C platform has been analyzed.

At the same time, ecommerce satisfaction has been studied widely [28], although few literatures have combined this topic with the IAM framework. This aspect is identified as the main novelty of the present article. In this manner, this article is an attempt to fill this gap. Specifically, the present article proposes to define a model that integrates both points of view to enrich knowledge in this field. To address this gap, we believe that ecommerce satisfaction can reinforce the IAM theoretical framework since satisfaction is crucial to obtain positive comments and responses in eWOM contexts. Indeed, this is our main contribution. Based on this premise, we have defined the following research question:

RQ. Can an IAM framework, in combination with an ecommerce satisfaction perspective, explain the eWOM communications' impact on purchase intention in C2C platforms?

The rest of this article is divided into six sections. Section 2 shows a literature review related to the topic of the research question. Section 3 exposes the theoretical frameworks and the hypotheses incorporated into the research model; Section 4 provides the method; Section 5 shows the findings and Section 6 discusses these findings. Finally, Section 7 includes the conclusions, indicating the limitations and the implications from the findings. 


\section{Literature Review}

Sharing information in ecommerce is an essential factor to increase consumer trust [29]. In the last decade, this information sharing has been moved from offline to online as a consequence of the development of Information and Communication Technologies (ICT), mainly social networks [30]. Companies, aware of this fact, are promoting ecommerce communication [18].

In this context, eWOM has played a key role in this transformative process as a way of consolidating the sharing of consumption emotions [31]. According to [32], emotions are one of the most influential factors in decision-making processes; eWOM is identified as a relevant medium to indicate emotions in virtual contexts. In this line, ref. [33] showed that consumers use eWOM to avoid risk associated with buying a product online. In this sense, increasing eWOM use is observed, while at the same time, there is growth in the skepticism toward advertising campaigns [34].

Thus, eWOM has been widely analyzed by studies related to purchase intention [35-42]. In this line, one of the first studies that addresses this relationship was conducted by [40]. These authors showed that eWOM has an indirect impact on purchase intention through the value co-creation dimension (the process by which companies and consumers collaborate to reach additional values). Therefore, the adopted point of view assumes that consumers are motivated by obtaining collective benefits. Therefore, this perspective largely omits the fact that consumers buy products or services mainly to satisfy needs.

In this manner, eWOM platforms collect positive and negative opinions from consumers as a reflection of the positive and negative emotions that come after purchasing products or services [33]. According to [43] nine positive emotions can be identified in eWOM: (1) amusement, (2) awe, (3), compassion, (4), contentment, (5) gratitude, (6) hope, (7) joy, (8) love and (9) pride. This study differs from [40]. It considers eWOM as a platform not only to share objective information about products and services, but also to manage emotions. In a similar way, ref. [44] demonstrated that negative contents in eWOM impact the cognition, reliability, and trust of consumers.

From this study, there have been many other works focused on eWOM and ecommerce, which can be classified into two groups [45]: (1) the amount of eWOM generated and (2) the effects of eWOM on some corporate dimensions, such as trust or loyalty. In addition, most of these studies are focused on eWOM use in B2C (business to consumer) or B2B (business to business) contexts [46]. In this manner, few investigations are identified related to the $\mathrm{C} 2 \mathrm{C}$ context, and some of them with disparate results.

Considering that, ref. [12] developed an eight constructs research model based on IAM to analyze the impact of variables, such as, (1) Perceived informativeness, (2) Perceived persuasiveness, (3) Source expertise, (4) Source trustworthiness, (5) eWOM usefulness, (6) eWOM credibility and (7) eWOM adoption. Thus, this work would be included in the group of studies that try to measure the effect of eWOM adoption. This model is focused on social networking sites applied to cosmetics consumers. However, this study does not incorporate satisfaction with the ecommerce process. At the same time, an investigation associated with eWOM and C2C conducted by [47] is identified. They do not find eWOM impact on customer repurchase intentions, although it influences customer perceptions of product value and the likelihood to recommend the product.

In addition, according to [48], satisfaction "is a post-activity measuring index that measures the interior state of the customer's feelings about past purchases and experiences of shopping". In this manner, satisfaction can be expressed in eWOM platforms in a similar way as emotions. Ecommerce satisfaction is considered a central dimension that can influence purchase processes [49]. According to [50], the use of this dimension provides an appropriate explanation for measuring ecommerce success. In this respect, ref. [51] identified a positive connection between ecommerce satisfaction and spending. Reference [52] demonstrated that trust influences ecommerce satisfaction, leading to purchase intention.

Considering the previous point, the present study proposed a model to test the eWOM impact on purchase intention based on IAM, where the ecommerce satisfaction is included 
as a determinant factor in ecommerce success. In the following, we expose the theoretical frameworks and hypotheses foundations.

\section{Research Hypotheses and Proposed Model}

The Information Adoption Model (IAM) was developed by [25]. This model tries to explain how people assume information to modify their intentions and behaviors within computer-mediated communication platforms [53]. This model arises from a combination of other theoretical frameworks, such as TAM or ELM. On the one hand, TAM is one of the most influential theoretical frameworks to explain ICT acceptance and to study the usage intention based on the principles proposed by [54] in the Theory of Reasoned Action (TRA). Thus, from TAM, it is extracted that attitude and individual internal belief of perceived usefulness jointly determine individual behavior intention [55]. On the other hand, ELM was developed by [56] to understand the effectiveness of persuasive communications [56]. In this manner, EML considers that an individual transforms its attitude and behavior through two routes [57]: (1) central and (2) peripheral. A central route is taken when a person possesses high motivation to obtain relevant information, while a peripheral route is activated with low motivations and abilities, applying simple heuristic cues to adopt a quick and easy position about an issue. In this manner, this second route requires less cognitive effort to process a message [58,59].

IAM is composed by four constructs [39]: (1) argument quality, (2) source credibility, (3) information usefulness and (4) information adoption. According to [12], "consumers screen and critique a certain piece of information centrally and peripherally to determine whether to follow the related recommendation, evaluating its usefulness". This framework has been widely applied in the ICT field. In this manner, ref. [60] used IAM to identify factors that encourage the adoption of online opinions for consuming goods or services. Similar research has applied this theory, sometimes integrating it with other frameworks in order to explain how people process persuasive information to make decisions $[55,61,62]$. In fact, according to IAM foundations [25], communication influences consumers' decision making when persuasive information is used.

Based on the prior literature, the present study tries to examine the effects of positive and negative feedback on purchase decision-making processes. Therefore, this article integrates (1) the IAM framework and (2) the ecommerce satisfaction framework to propose the research model as shown in Figure 1. According to both perspectives, the constructs that could have an impact on the purchase decision are analyzed as follows.

In this manner, this theoretical integration has excluded from the research model the constructs of information usefulness and information adoption proposed by [25]. Based on investigations, such as [12,39], eWOM information impacts purchase intention. Therefore, according to [63], marketing campaigns "should be developed with high argument quality, followed by high source credibility and a large amount of information on social media". Thus, we have defined direct connections between the constructs of argument quality and source credibility with purchase intention. The justifications for the definition of the hypotheses are shown in the next epigraphs. 


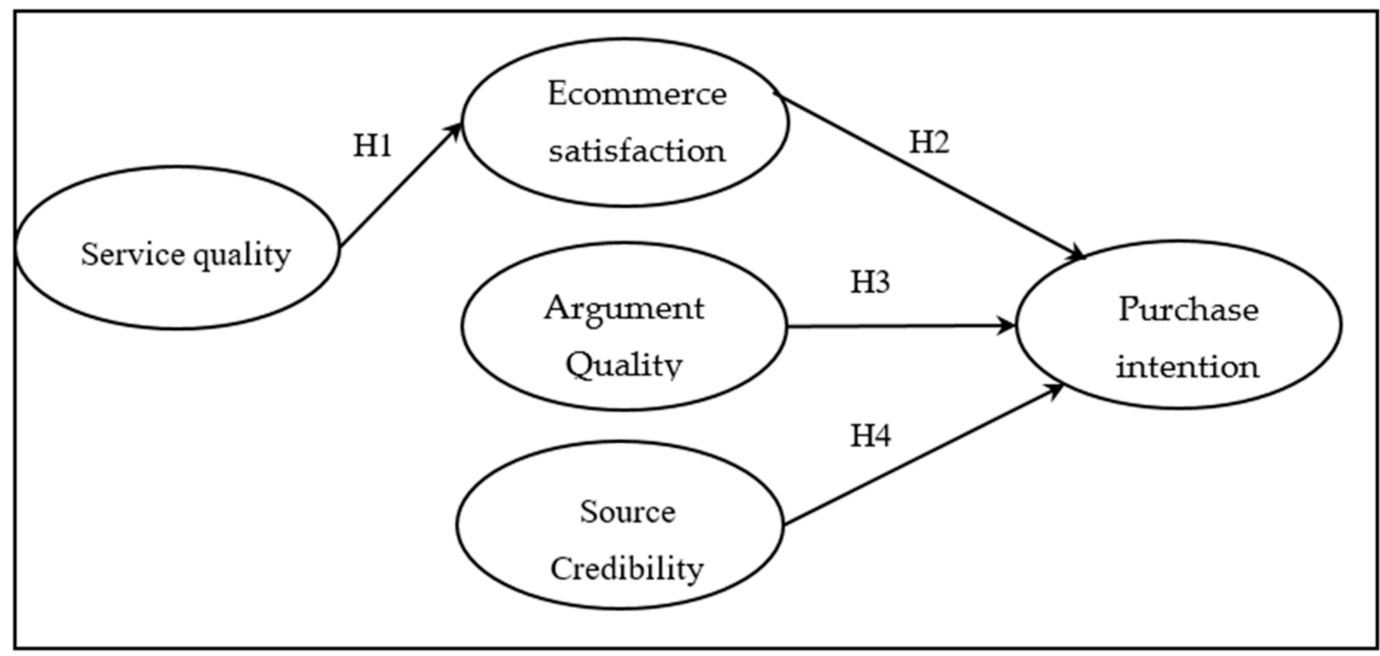

Figure 1. IAM-based research model.

\subsection{Service Quality and Ecommerce Satisfaction}

According to [64], service quality is refers to "a contrast of perceptions and expectations of customers about the service". In this way, service quality depends on an individual's evaluation of the online service, including factors such as reliability, responsiveness, assurance, personalization [65] and types of message [66]. Thus, service quality is one of the most important dimensions when companies try to assess customer relationships [67]. In fact, the existence of models, such as E-S-QUAL, is an attempt to measure electronic service quality, especially for collaborative consumption [68], which is focused on four quality factors: (1) efficiency, (2) fulfilment, (3) system availability and (4) privacy [69]. Many investigations have analyzed service quality in C2C platforms. In this line, ref. [70] determined that a way of reaching service quality in sharing economy platforms could be to implement platform-mediated rating for reputation systems. In fact, based on [71], currently, platform service quality management has become an important research topic.

In addition, recent studies have shown the need to investigate the relationship between eWOM satisfaction and purchase behaviors [13]. Indeed, knowing the level of ecommerce satisfaction is one of the most important tasks of digital marketing [72]. In a general way, eWOM contexts generate a positive effect on ecommerce satisfaction [73]. In particular, ref. [74] an individual's satisfaction with $\mathrm{C} 2 \mathrm{C}$ commerce is influenced by some dimensions related to service quality, such as empathy, responsiveness, reliability, and assurance. In this same line, ref. [75] highlighted the reliability dimension as the one capable of reinforcing satisfaction or trust. In a similar way, ref. [76] identified reliability as the most critical factor for assessing the perceived value and satisfaction with online retailers. In this respect, it is convenient to differentiate the concepts of perceived value and satisfaction. While the first refers to the balance between the perceived benefit and cost, the second is the perception of the experience after consuming a good or service $[77,78]$.

In addition, positive emotions have a positive effect on customer satisfaction [79]. Thus, obtaining satisfaction positively affects trust, especially in virtual contexts [7]. According to [80], C2C-platform trust is more complex than that of other ecommerce models due to the detection of two factors: (1) the identities of sellers and buyers are not very transparent, and (2) the presence of information asymmetry. Delving into this idea, ref. [81] demonstrated the relationships between service quality, satisfaction, and loyalty in online services. Hence, this study proposes that service quality is one of the main factors that determine ecommerce satisfaction and this, in turn, impacts purchase intention. In this sense, the following hypotheses are suggested:

Hypothesis 1 (H1). Service quality positively impacts ecommerce satisfaction. 
Hypothesis 2 (H2). Ecommerce satisfaction positively impacts purchase intention.

\subsection{Argument Quality}

Based on IAM principles [25], the information quality conditions the degree of information influence. Thus, argument quality has been widely applied in studies that analyze the informational influence in C2C contexts [12,64,82]. According to [82], argument refers to the set of shopping advice from other consumers, which are considered for purchase decision making. In this manner, two dimensions are identified [12]: (1) informativeness, which includes aspects such as comprehensiveness, timeliness, and relevance of the received information, and (2) persuasiveness. Indeed, argument has a greater impact on attitude change [83]. In this line, ref. [84] insisted in the presence of positive and negative messages in eWOM. These authors proposed that ecommerce platform managers should incentivize the sharing of more positive factual information and sort them by the subject matter. In this sense, argument quality is linked with substantial strength to argue with a message [64].

In a virtual context, such as $\mathrm{C} 2 \mathrm{C}$ platforms, argument quality can be reinforced with visual contents, such as image or video [85]. This type of information should support a more efficient decision-making process regarding the purchase of goods or services [86]. In this respect, it is relevant to consider that a message with strong arguments persuades better than a message with weak arguments [87]. According to [88], argument quality significantly impacts on purchase dimensions, such as, consumers' likes and share intentions. In this respect, it should be clarified that this impact could be different depending on whether they are utilitarian or hedonic goods [89]. Thus, the argument quality construct is associated with utilitarian product purchases because they require a lot of cognitive effort to process a message [90], which would be related to the central route in ELM. In this manner, argument quality is considered an important central cue in a persuasive information process [82]. Therefore, it is expected that the argument quality of the messages in $\mathrm{C} 2 \mathrm{C}$ platforms influences purchase intention. In this manner, the following hypothesis is proposed:

Hypothesis 3 (H3). Argument quality positively impacts purchase intention.

\subsection{Source Credibility}

Along with argument quality, source credibility is a qualified dimension to understand information adoption. Thus, source credibility is related to the receiver's trust toward the source of the information [64]. In the IAM framework, source credibility is considered a peripherical route [91], which behaves as a contextual and less-important dimension in message persuasion [92]. In this manner, according to [93], source credibility has a high impact on consumers' opinions. In fact, previous literature has shown the credibility impact on consumer purchase intention [94,95].

In particular, source credibility plays a relevant role in an eWOM context. According to [96], recommendation sidedness and the volume of recommendations are the two most studied stimulus cues in eWOM. In a similar way, ref. [97] considered that eWOM credibility has a positive impact on e-WOM adoption. In fact, online discussions and opinions between consumers may generate more credibility and empathy than marketer-generated web content [44]. eWOM is a way to help other consumers to make good purchase decisions [98]. However, ref. [99] demonstrated that consumers with low confidence in online recommendations consider only non-paid, genuine reviews as credible. Source credibility of the message in $\mathrm{C} 2 \mathrm{C}$ platforms impacts purchase intention, and the following hypothesis is formulated:

Hypothesis 4 (H4). Source credibility positively impacts purchase intention. 


\subsection{Individual Moderators}

Some variables have been incorporated into the analysis, which moderate the relationships previously described in the hypotheses from $\mathrm{H} 1$ to $\mathrm{H} 4$. In this respect, many PLS-SEM-based investigations frequently omit the moderating impacts of individual dimensions. At the same time, many studies have highlighted the importance of included moderator variables to enrich the understanding of a field. Thus, gender and age have been extensively analyzed as a core moderator variable in PLS-SEM-based models. Specifically, focusing on IAM-based investigations, gender and age have provided significant evidence to extract findings through which knowledge in the field has been improved.

In this respect, age is frequently incorporated when considering different age groups or age ranges [100] to obtain disparate findings. In a general way, age has a significant impact on virtual contexts [101]. For example, ref. [82], after completing a moderator analysis, confirmed that different age groups have specific moderating effects on mobile health services adoption. Reference [102] demonstrated the moderating effect of age on internet use for banking operations. However, some investigations are identified that have not could demonstrated this moderator effect. This is the case of the study conducted by [103] which did not observe the significant impact of age on internet banking services.

In a similar way, gender is a classic moderating variable in studies related to ICT, especially in electronic-based technologies [104]. Traditionally, gender has been incorporated in ecommerce studies in order to analyze the differences by sex, particularly to support marketing strategies [105]. Prior literature has determined that men and women behave differently in electronic contexts [106]. Concretely, ref. [107] revealed that women are more risk-averse than males in an online-based economy context, but women possess a purchase competitive nature. Therefore, the following hypotheses have been formulated, describing the moderating effect of gender and age on the relationships between independent and dependent variables:

Hypothesis 5 (H5). Purchase intention is different depending on gender.

Hypothesis 6 (H6). Purchase intention is different depending on age.

The proposed hypotheses are summarized in Table 1. In this table, the constructs included in each hypothesis are shown, using the short name that will be employed in the analysis.

Table 1. Summary of hypotheses.

\begin{tabular}{cccc}
\hline Hypothesis & Construct 1 & Construct 2 & Description \\
\hline H1 & Service Quality & Ecommerce Satisfaction & SQ » SF: SQ impacts positively SF \\
H2 & Ecommerce Satisfaction & Purchase Intention & SF » PI: SF impacts positively PI \\
H3 & Argument Quality & Purchase Intention & AQ » PI: AQ impacts positively PI \\
H4 & Source Credibility & Purchase Intention & SC » PI: SC impacts positively PI \\
H5 & Gender & Purchase Intention & GEN » PI: PI is different depending on GEN \\
H6 & Age & Purchase Intention & AGE » PI: PI is different depending on AGE \\
\hline
\end{tabular}

\section{Methods}

The study was conducted in the first semester of 2020. It used a self-administered web-based questionnaire. The main survey questionnaire employed a random sample of Taobao consumers. The participants were previously informed of the research aims. The web-based questionnaire was supported by Google Form. In addition, this questionnaire was defined considering evidence from prior research on the IAM framework and ecommerce satisfaction literature. Specifically, the measuring scale for the constructs included in the research model was defined with the measures from the sources shown in the Appendix A. In fact, the measurement scale was developed based on [7,12,50,82,108,109]. 
Specifically, the questionnaire was structured into two sections. In the first one, responders provided demographic information (Table 2). In the second part, participants indicated their agreement or disagreement with 17 items, using a five-point Likert-type scale, ranging from "not at all/strongly disagree" (1) to "exactly/strongly agree" (5). The 17 items (Appendix A) were grouped into the five constructs of the model. In this respect, a total of 129 consumers completed the survey. Finally, 116 responses were valid. Thus, 13 responses were excluded because they were not properly filled.

Table 2. Demographic profile of the participants.

\begin{tabular}{cccc}
\hline Variable & Characteristic & $\mathbf{N}$ & $\mathbf{\%}$ \\
\hline \multirow{3}{*}{ Gender (GEN) } & Male & 56 & $48.28 \%$ \\
& Female & 60 & $51.72 \%$ \\
& Total & 116 & $100.00 \%$ \\
\hline \multirow{3}{*}{ Age (AGE) } & $18-20$ & 25 & $21.55 \%$ \\
& $20-24$ & 27 & $23.28 \%$ \\
& $25-29$ & 21 & $18.10 \%$ \\
& $30-34$ & 11 & $9.48 \%$ \\
& $35-39$ & 11 & $9.48 \%$ \\
& $40-44$ & 8 & $6.90 \%$ \\
& +45 & 13 & $11.21 \%$ \\
& Total & & $100.00 \%$ \\
\hline
\end{tabular}

The quantitative data analysis included two processes: (1) an analysis of the descriptive statistics and the reliability of the measurement, using the SPSS v. 24 statistical software; and (2) PLS-SEM testing. In this respect, the software Smart PLS v. 3.3.2. allowed to evaluate the correlation coefficient between variables in factor analysis and the path analysis of the equation model. A detailed explanation of the application of both analytical procedures and results is given in Section 5.

\section{Results}

Before testing the model, it is crucial to assess the fit model. Thus, a twofold analysis was completed to test the validity of the measurement model: (1) evaluating the reliability and (2) studying the discriminant and convergent validity. In addition, the common method bias (CMB) was used to analyze the collinearity inside the model.

\subsection{Internal Consistency Reliability and Validity}

On the one hand, the Cronbach's alpha and composite reliabilities were used to assess the item loadings and internal consistency reliability. On the other hand, the convergent validity and discriminant validity for the latent constructs were evaluated with a confirmatory factor analysis (Table 3).

Table 3. Item loadings and measurement reliability.

\begin{tabular}{cccccc}
\hline Construct & Item & $\begin{array}{c}\text { Item Reliability } \\
\text { (Loading) }\end{array}$ & $\begin{array}{c}\text { Cronbach's } \\
\text { Alpha }\end{array}$ & $\begin{array}{c}\text { Composite } \\
\text { Reliability }\end{array}$ & $\begin{array}{c}\text { Average Variance } \\
\text { Extracted (AVE) }\end{array}$ \\
\hline $\begin{array}{c}\text { Service } \\
\text { quality }\end{array}$ & SQ1 & 0.862 & 0.876 & 0.922 & 0.798 \\
(CQ) & SQ2 & 0.912 & & & \\
\hline SQ3 & 0.905 & & & \\
Ecommerce & SF1 & 0.864 & 0.861 & 0.915 & \\
satisfaction & SF2 & 0.904 & & & \\
(SF) & SF3 & 0.884 & & & \\
\hline
\end{tabular}


Table 3. Cont.

\begin{tabular}{cccccc}
\hline Construct & Item & $\begin{array}{c}\text { Item Reliability } \\
\text { (Loading) }\end{array}$ & $\begin{array}{c}\text { Cronbach's } \\
\text { Alpha }\end{array}$ & $\begin{array}{c}\text { Composite } \\
\text { Reliability }\end{array}$ & $\begin{array}{c}\text { Average Variance } \\
\text { Extracted (AVE) }\end{array}$ \\
\hline Argument & AQ1 & 0.926 & 0.918 & 0.942 & 0.802 \\
$\begin{array}{c}\text { Quality } \\
\text { (AQ) }\end{array}$ & AQ2 & 0.909 & & & \\
& AQ3 & 0.840 & & & \\
\hline & & 0.907 & & & 0.715 \\
Source & SC1 & 0.789 & 0.869 & & \\
Credibility & SC2 & 0.872 & & & \\
(SC) & SC3 & 0.856 & & & \\
& SC4 & 0.864 & & & \\
\hline \multirow{2}{*}{$\begin{array}{c}\text { Purchase } \\
\text { intention }\end{array}$} & PI1 & PI2 & 0.938 & 0.935 & \\
(PI) & PI3 & 0.932 & & & \\
\hline
\end{tabular}

In this way, the convergent validity was evaluated, observing the item factor loadings. In this respect, in a first step, two thresholds must be exceeded to affirm the convergent validity: (1) all item factor loadings must be greater than 0.70 , and (2) all composite reliabilities for each construct in the model must be well above 0.70 . In this sense, both restrictions were overcome. Additionally, the Average Variance Extracted (AVE) must exceed 0.50 for each construct [110] to definitively affirm the convergent validity, and the loadings for all constructs with reflective measures have to be greater than 0.70 and statistically significant in 0.001 [111]. In this manner, these two conditions are also met. In particular, the AVE values ranged from 0.715 to 0.827 , well above 0.50 .

Otherwise, discriminant validity measures the degree to which a construct is different from the other constructs. It is important to establish discriminant validity to ensure that the result is robust and there are no statistical discrepancies in the results. Thus, to affirm the discriminant validity, the following two conditions must be met: (1) the square root of the AVE should be larger than the inter-construct correlations and (2) the factor loadings must be greater in the representative constructs than any other in the model [112].

In addition, the diagonal elements of the correlation matrix (Table 4) have been replaced by the square root of the AVE (in bold) for comparison purposes. On the one hand, in all the cases, the square roots of the AVE were larger than the inter-construct correlations, and all shared variances between any two different constructs were less than the amount of variance extracted by one of the two constructs [113]. On the other hand, all items loaded more strongly on their corresponding constructs than on other constructs [112]. Therefore, these results confirm the discriminant validity of all constructs. In addition, the heterotraitmonotrait (HTMT) criterion was analyzed (Table 4). The HTMT is the evaluation of the correlation of indicators across concepts measuring different phenomenon [112]. The discriminant validity is established if the value of HTMT is less than 0.9 [112]. In this manner, Table 4 shows the output from the HTMT analysis, confirming the discriminant validity of the items.

Table 4. Correlation matrix and heterotrait-monotrait criterion. Text in bold is the diagonal elements of the correlation matrix.

\begin{tabular}{|c|c|c|c|c|c|c|c|c|c|c|}
\hline & \multicolumn{5}{|c|}{ Correlation Matrix } & \multicolumn{5}{|c|}{ Heterotrait-Monotrait (HTMT) } \\
\hline & SQ & SF & AQ & SC & PI & SQ & SF & $\mathrm{AQ}$ & $\mathrm{SC}$ & PI \\
\hline Service quality (SQ) & 0.893 & & & & & & & & & \\
\hline Ecommerce satisfaction (SF) & 0.239 & 0.884 & & & & 0.270 & & & & \\
\hline Argument Quality (AQ) & 0.230 & 0.342 & 0.895 & & & 0.254 & 0.380 & & & \\
\hline Source Credibility (SC) & 0.278 & 0.281 & 0.540 & 0.845 & & 0.322 & 0.333 & 0.602 & & \\
\hline Purchase Intention (PI) & 0.013 & 0.276 & 0.371 & 0.331 & 0.909 & 0.056 & 0.310 & 0.401 & 0.364 & \\
\hline
\end{tabular}




\subsection{Common Method Bias (CMB)}

The common method bias (CMB) tries to measure the shared common variation between indicators. This analysis of the collinearity is recommended when the same source of data is used for the independent and dependent variables in a PLS-SEM model. In this manner, a full collinearity test based on variance inflation factors (VIFs) was applied to assess vertical and lateral collinearity $[114,115]$. In particular, pathological collinearity can be affirmed when the VIF values are above 3.3 [114]. Considering that threshold, it can be affirmed that the present study lacks CMB (Table 5).

Table 5. Inner VIF values.

\begin{tabular}{cc}
\hline Construct & VIF \\
\hline AQ & 1317 \\
PI & 1170 \\
PS & 1178 \\
SC & 1087 \\
SQ & 1118 \\
\hline
\end{tabular}

\subsection{Model Test}

The path coefficients of the model were estimated with the Smart PLS software v. 3.3.2. The bootstrapping procedure with 5000 samples was used to generate the path coefficient relationships in the proposed model, $\mathrm{t}$-value, standards errors, and the variance explained for the dependent variables (Figure 2 and Table 6).

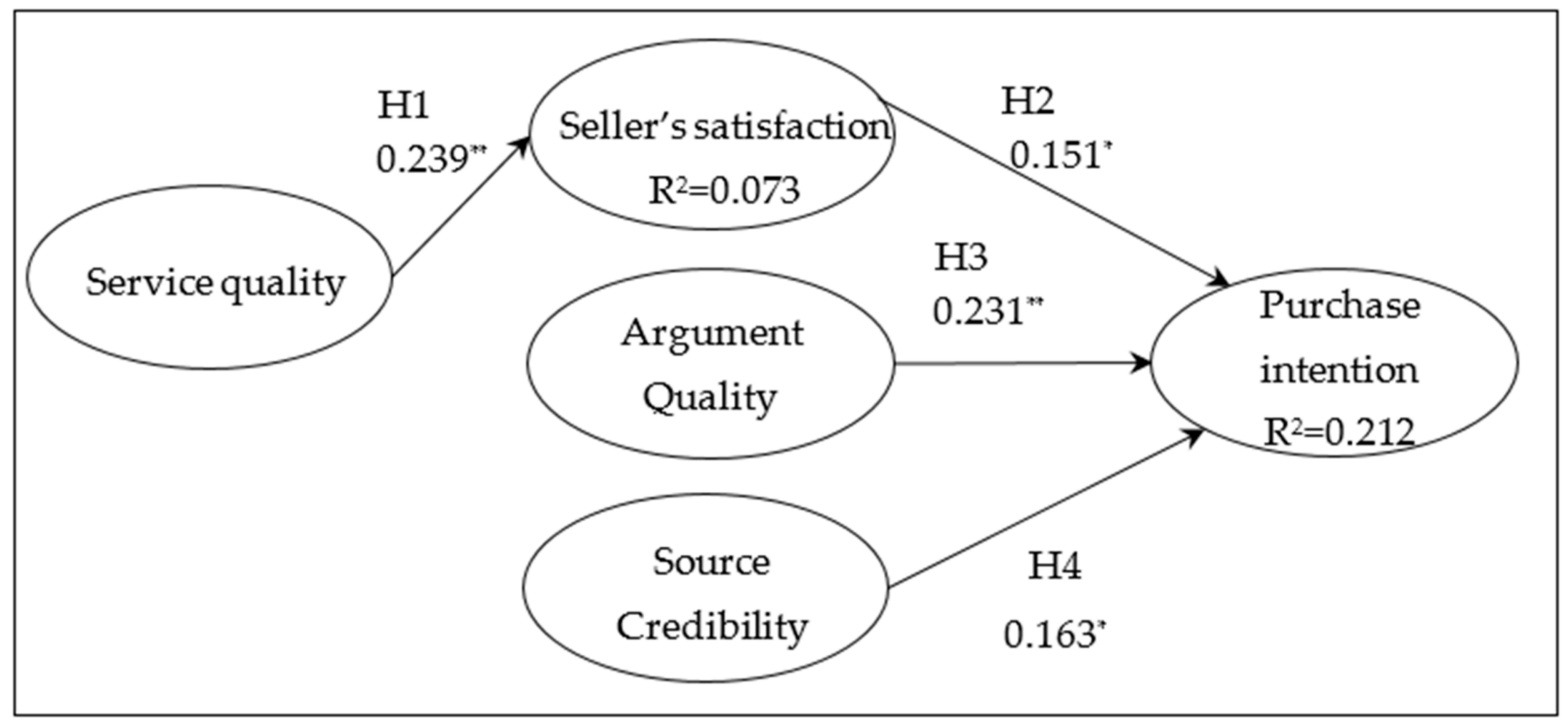

Figure 2. Test model. ${ }^{*} p<0.05 \mathrm{t}(0.05 ; \infty)=1.9670 ;{ }^{* *} p<0.01 \mathrm{t}(0.01 ; \infty)=2.5904$.

Table 6. Results of hypothesis testing.

\begin{tabular}{ccccccc}
\hline Hypothesis (Path) & Path Coefficient $(\boldsymbol{\beta})$ & Supported & Women $(\boldsymbol{\beta})$ & Men $(\boldsymbol{\beta})$ & Younger $(\boldsymbol{\beta})$ & Older $(\boldsymbol{\beta})$ \\
\hline H1: SQ $»$ SF & $0.239^{* *}$ & Yes & $0.439^{* * *}$ & 0.168 & 0.214 & 0.282 \\
H2: SF » PI & $0.151^{*}$ & Yes & 0.289 & 0.074 & 0.016 & $0.292^{* *}$ \\
H3: AQ »PI & $0.231^{* *}$ & Yes & $0.324^{* * *}$ & $0.204^{*}$ & $0.305^{*}$ & $0.210^{*}$ \\
H4: SC $\gg$ PI & $0.163^{*}$ & Yes & 0.13 & 0.209 & $0.287^{* *}$ & 0.104 \\
\hline
\end{tabular}

Note: Significant at: ${ }^{*} p<0.05 \mathrm{t}(0.05 ; \infty)=1.9670 ;{ }^{* *} p<0.01 \mathrm{t}(0.01 ; \infty)=2.5904 ;{ }^{* * *} p<0.001 \mathrm{t}(0.001 ; \infty)=3.3195$. 
These results demonstrate that all the hypotheses were supported as the defined relationships. As shown in Figure 2, the proposed research model explains $21.2 \%$ of the purchase intention. Particularly, ecommerce satisfaction $(\beta=0.151 p<0.05)$, argument quality $(\beta=0.231, p<0.01)$ and source credibility $(\beta=0.163, p<0.05)$ are significant predictors of purchase intention. Additionally, this study identified that service quality explains the $7.3 \%$ of ecommerce satisfaction, having good significance $(\beta=0.239, p<0.01)$.

\subsection{Moderator Effects}

The hypotheses about the moderator effects were tested by comparing the path coefficients for the formed groups in each moderator variable. In this respect, a multi-group analysis was applied to test the moderator effects of gender and age. Thus, respondents were divided into two groups: (1) male-female consumers and (2) younger-older consumers. Regarding the age, the group of younger people comprises consumers up to 24 years of age, while the other group is made up of consumers aged 25 and over. Based on these groups, four models were examined to analyze their moderator effects on the purchase intention construct. All the models obtained significant results. Table 6 shows the results of the path coefficient comparisons.

Considering the results by gender, they demonstrate that the path coefficients had different behaviors for males and females. On the one hand, all the hypotheses for male consumers have not been met, excepting $\mathrm{H} 3$, although this relationship had little significance $(\beta=0.204, p<0.05)$. In this manner, argument quality was the only construct that had a positive impact on purchase intention. However, the model for females reached results that were more significant. Thus, the last hypotheses $\mathrm{H} 1$ and $\mathrm{H} 2$ were met widely ( $\beta=0.439, p<0.001$ and $\beta=0.324, p<0.001$, respectively), indicating that women pay more attention to consumers' opinions than men, especially to those aspects related to the quality, either about the services or about the arguments.

Regarding the age, the model obtained different results for younger and older people. In this way, both groups have considered argument quality as a predictor of purchase intention $(\beta=0.305, p<0.05$ for younger and $\beta=0.210, p<0.05)$ for older. However, ecommerce satisfaction is a good predictor of purchase intention for older people $(\beta=$ $0.292, p<0.01$ ) but not for younger people. In a similar way, source credibility is a good predictor of purchase intention for younger people $(\beta=0.287, p<0.01)$, but not for older consumers. The relationship between service quality and ecommerce satisfaction was not significant for both groups.

\section{Discussions}

This study carried out an investigation about the connections between consumer relationships and purchase intention in $\mathrm{C} 2 \mathrm{C}$ contexts. Concretely, the significance of the constructs' service quality, ecommerce satisfaction, argument quality, and source credibility with purchase intention was analyzed. Considering this purpose, the IAM framework was applied in combination with an ecommerce satisfaction perspective.

In this manner, the IAM foundations allowed to define a model capable of achieving the research aim. Specifically, this model clarified the relevance of peer communications and relationships in $\mathrm{C} 2 \mathrm{C}$ purchases. In addition, it identified some dimensions to examine some motivations to use these types of ecommerce platforms to satisfy needs. Based on [25], communication processes impact consumer decision-making processes through persuasive information. In this respect, according to [12], consumers have the ability to filter the information that they receive based on its usefulness.

Based on these principles, the present study makes some contributions under a theoretical perspective. Table 7 summarizes them. First, it defined a comprehensive model that enhance knowledge about the main predictors that stimulate consumption via $\mathrm{C} 2 \mathrm{C}$ platforms. In fact, the results noted the dimensions that condition $\mathrm{C} 2 \mathrm{C}$ online purchases. Second, these findings allow to improve the understanding of the purchase intention in C2C platforms. In this manner, the dataset provided a solid endorsement of the model, 
which was proposed after analyzing the background of the field. Specifically, as expected, all the proposed hypotheses were supported.

Table 7. Summary of findings by hypothesis.

\begin{tabular}{|c|c|c|}
\hline Hypothesis & Description & Findings, Theoretical Contributions and Management Implications \\
\hline $\mathrm{H} 1$ & $\begin{array}{c}\mathrm{SQ} » \mathrm{SF}: \mathrm{SQ} \text { impacts } \\
\text { positively SF }\end{array}$ & $\begin{array}{l}\text { - It was supported by the findings. Thus, service quality (SQ) influence } \\
\text { ecommerce satisfaction (SF). } \\
\text { - The findings ratify the defined relationship in contexts related to C2C } \\
\text { platforms. } \\
\text { - Individual's satisfaction in } \mathrm{C} 2 \mathrm{C} \text { commerce is influenced by service } \\
\text { quality. } \\
\text { These findings are in line with prior studies, such as [75-77]. }\end{array}$ \\
\hline $\mathrm{H} 2$ & $\begin{array}{c}\mathrm{SF} » \mathrm{PI}: \mathrm{SF} \text { impacts } \\
\text { positively PI }\end{array}$ & $\begin{array}{l}\text { - It was supported by the findings. Thus, ecommerce satisfaction (SF) } \\
\text { influences purchase intention (PI). } \\
\text { - The ecommerce satisfaction supports the growth of sales [19]. } \\
\text { These findings allow affirming that consumers consider dimensions } \\
\text { related to satisfaction to make decisions related to purchases. }\end{array}$ \\
\hline
\end{tabular}

$\mathrm{H} 3$

\section{$A Q » P I: A Q$ impacts positively PI}

\section{SC » PI: SC impacts positively PI}

- It was supported by the findings. Thus, argument quality (AQ) influences purchase intention (PI).

- Argument quality is considered an important central cue in a persuasive information process in $\mathrm{C} 2 \mathrm{C}$ platforms.

- $\quad$ The relevance of the role of information transmission coming from communications in online (C2C) relationships was demonstrated.

- It was supported by the findings. Thus, source credibility (SC) influences purchase intention (PI).

- $\quad$ SC was identified as a qualified dimension to understand the purchase intention in $\mathrm{C} 2 \mathrm{C}$ platforms.

- $\mathrm{SC}$ is related to the receiver trust toward the source of information, impacting on consumers' opinions.

- This result is in line with previous literature [91-94]. depending on GEN
- $\quad$ The model demonstrates that the path coefficients have had different behavior for males and females.

- Argument quality was the only construct that had a positive impact on purchase intention for male.

- The model for female reached results more significant.

- Women pay more attention to other consumers' opinions than men.

- The model obtained different results for younger or older people.

- $\quad$ Both groups considered argument quality as a predictor of purchase intention.

- $\quad$ Ecommerce satisfaction is a good predictor of purchase intention for older people, but not for younger people.

H6 AGE » PI: PI is differen depending on AGE
- $\quad$ Source credibility is good predictor of purchase intention for younger people.

- The relationship between service quality and ecommerce satisfaction was not significant in both groups.

In this respect, according to [67], service quality is one of the most important dimensions when companies try to assess customer relationships. In addition, ref. [74] identified that the individual's satisfaction in C2C commerce is influenced by service quality. In 
fact, ref. [81] demonstrated the relationships between service quality and satisfaction in electronic contexts. Thus, the findings ratify this relationship in $\mathrm{C} 2 \mathrm{C}$ platforms, adopting some likenesses regarding the prior research [75-77]. In this manner, hypothesis H1 was met as supposed. In a similar way, this ecommerce satisfaction impacted purchase intention in $\mathrm{C} 2 \mathrm{C}$ platforms, meeting H2. As was described in Section 3.1, obtaining satisfaction positively affects trust, especially in virtual contexts [7], although C2C-platform trust is more complex than other ecommerce methods [80]. In this respect, the prior literature showed that, in a general way, the use of eWOM supports the growth of sales [19]. At the same time, these findings allow to affirm that consumers consider the trust dimension to make decisions related to purchases [14], such as satisfaction. From this, it can be deduced that the exchange of information using eWOM platforms is considered more trustworthy than other ways or sources. This idea is shared with previous research [21].

Additionally, argument is referred to as the shopping advice from other consumers, influencing making purchase decisions [82], with informativeness and persuasiveness being two essential attributes [12]. Argument quality in eWOM contexts is linked with substantial strength to argue with a message [64]. Specifically, argument quality is considered an important central cue in a persuasive information process in $\mathrm{C} 2 \mathrm{C}$ platforms [82]. In this manner, as expected, this relationship was supported by the dataset. The model tested that $\mathrm{C} 2 \mathrm{C}$ argument quality has an impact on purchase intention, demonstrating the relevance of the role played by information transmission coming from communications in C2C relationships. Similarly, based on the results, source credibility was identified as a qualified dimension for understanding purchase intention in $\mathrm{C} 2 \mathrm{C}$ platforms. In this manner, according to [64], source credibility is related to the receiver's trust toward the source of information, impacting consumers' opinions. In fact, the previous literature has shown the influence of credibility on consumer purchase intentions [94]. Therefore, the hypotheses $\mathrm{H} 3$ and $\mathrm{H} 4$ were met.

\section{Conclusions}

The present work was an attempt to test the purchase intention in C2C platforms, mainly applying the IAM framework. In this respect, the definition of a PLS-SEM model allowed to draw relevant conclusions about the role of information transmission coming from online communications in $\mathrm{C} 2 \mathrm{C}$ relationships. In addition, based on the findings obtained, it was possible to identify the factors that, within the $\mathrm{C} 2 \mathrm{C}$, incentivize purchase intention. They include (1) service quality, (2) ecommerce satisfaction, (3) argument quality and (4) source credibility. In fact, the findings have provided useful data for clarifying the most relevant factors that impact purchase intentions. Overall, the present analysis clearly confirms that the success of $\mathrm{C} 2 \mathrm{C}$ platforms could be determined by dimensions related to the direct relationships between consumers, which allow generating trust to complete a purchase. In a similar way, in answering the research question, we can affirm the validity of IAM to explain the eWOM impact on purchase intention in combination with an ecommerce satisfaction perspective.

In this manner, the $\mathrm{C} 2 \mathrm{C}$ ecommerce field can benefit from these findings. In fact, some implications are proposed. First, this study extended knowledge about $\mathrm{C} 2 \mathrm{C}$ ecommerce. In this way, additional empirical evidence has been provided for ulterior research to evaluate the purchase intention in $\mathrm{C} 2 \mathrm{C}$ enabling new advances in the field. Second, adopting a managerial view, comprehending the dimensions associated with online purchases is profitable for the $\mathrm{C} 2 \mathrm{C}$ online platforms. In this manner, these findings suggest that C2C platforms should strengthen the analyzed connections to grow the business and to promote transactions. Particularly, the results may be helpful for $\mathrm{C} 2 \mathrm{C}$ online platforms in determining the requirements to preserve their users and enhance the purchase experience.

Based on these implications, companies should comprehend the relevance of managing eWOM communications as one of the most influential dimensions in $\mathrm{C} 2 \mathrm{C}$ purchases. In this respect, companies should pay attention to ecommerce user satisfaction since it is considered a central dimension that can influence purchase intention. Thus, we recommend 
companies to invest in improving their ecommerce service quality to bolster consumers' positive opinions and emotions after buying products or services. Moreover, eWOM could boost the $\mathrm{C} 2 \mathrm{C}$ development as a way to enhance a collaborative economy. From this point of view, eWOM would assume an important social role in the better management of economic resources.

In addition, some limitations are identified in the present research. The first limitation is related to the explanatory capacity of the model. In this respect, the percentage of the explained variance for purchase intention could have improved with the incorporation of other dimensions associated with consumers' perceptions and motivations. The second weakness is linked to the sample. On the one hand, the findings are limited to the case of Taobao. In this manner, it would be advisable to design studies that include the consumer opinions of other $\mathrm{C} 2 \mathrm{C}$ platforms. On the other hand, although the results were statistically significant, a larger sample size would have contributed to more robust conclusions. Finally, a third limitation is related to the small number of moderate variables. Additional individual moderators could be added, such as education level, income level and marital status, among others.

Considering these limitations and the findings, some future work can be addressed. The first direction is related to a comparative study between the individual consumers from different countries or regions, incorporating more moderators. This study could enrich our knowledge about this topic. Finally, it would be interesting to develop these types of studies by combining them with new tendencies in ecommerce, for example, we refer to the possibility of combining the eWOM analysis with the analysis of consumers' behaviors when they navigate ecommerce websites with eye-tracking technologies [116].

Author Contributions: Conceptualization, S.B. and M.D.G.; methodology, S.B. and M.D.G.; software, M.D.G.; validation, S.B. and M.D.G.; formal analysis, S.B. and M.D.G.; investigation, S.B. and M.D.G.; resources, S.B. and M.D.G.; data curation, S.B. and M.D.G.; writing-original draft preparation, S.B. and M.D.G.; writing-review and editing, S.B. and M.D.G.; visualization, S.B. and M.D.G.; supervision, S.B. and M.D.G.; project administration, S.B. and M.D.G.; funding acquisition, S.B. and M.D.G. All authors have read and agreed to the published version of the manuscript.

Funding: This research received no external funding.

Institutional Review Board Statement: Not applicable.

Informed Consent Statement: Informed consent was obtained from all subjects involved in the study.

Data Availability Statement: Not applicable.

Conflicts of Interest: The authors declare no conflict of interest.

\section{Appendix A}

Table A1. Questionnaire.

\begin{tabular}{ccc}
\hline Construct & & Item \\
\hline & & Taobao stands out for having an adequate: \\
Service quality (SQ) & SQ1 & Transmission (order) time \\
& SQ2 & Easiness of searching information \\
& SQ3 & Solving customer's inconvenience \\
\hline Ecommerce & Overall, I consider this ecommerce satisfaction items when I am purchasing in Taobao: \\
satisfaction (SF) & SF1 & Seller reputation \\
& SF2 & Comments of other buyers \\
& SF3 & Satisfaction of other buyers \\
\hline
\end{tabular}


Table A1. Cont.

\begin{tabular}{|c|c|c|c|}
\hline Construct & & Item & Source \\
\hline $\begin{array}{c}\text { Argument Quality } \\
\text { (AQ) }\end{array}$ & $\begin{array}{l}\text { AQ1 } \\
\text { AQ2 } \\
\text { AQ3 } \\
\text { AQ4 }\end{array}$ & $\begin{array}{l}\text { the information provides during the process of purchase in Taoba } \\
\text { Informative } \\
\text { Valuable } \\
\text { Persuasive } \\
\text { Helpful }\end{array}$ & [82] \\
\hline $\begin{array}{l}\text { Source Credibility } \\
\text { (SC) }\end{array}$ & $\begin{array}{l}\text { SC1 } \\
\text { SC2 } \\
\text { SC3 } \\
\text { SC4 }\end{array}$ & $\begin{array}{l}\text { Overall, sellers who use Taobao are: } \\
\text { Knowledgeable } \\
\text { Credible } \\
\text { Expert } \\
\text { Trustworthy }\end{array}$ & [82] \\
\hline $\begin{array}{l}\text { Purchase intention } \\
\text { (PI) }\end{array}$ & $\begin{array}{l}\text { PI1 } \\
\text { PI2 } \\
\text { PI3 }\end{array}$ & $\begin{array}{c}\text { In the future: } \\
\text { Based on the chance, I would consider purchasing goods using } \\
\text { Taobao in the future } \\
\text { Based on the opportunity, I intend to purchase good using Taobao } \\
\text { Probably, before buying a good, I will look for it in Taobao }\end{array}$ & {$[7,12,82]$} \\
\hline
\end{tabular}

\section{References}

1. Abbes, I.; Hallem, Y.; Taga, N. Second-Hand Shopping and Brand Loyalty: The Role of Online Collaborative Redistribution Platforms. J. Retail. Consum. Serv. 2020, 52, 101885. [CrossRef]

2. Huber, A. Theorising the Dynamics of Collaborative Consumption Practices: A Comparison of Peer-to-Peer Accommodation and Cohousing. Environ. Innov. Soc. Transit. 2017, 23, 53-69. [CrossRef]

3. Casprini, E.; di Minin, A.; Paraboschi, A. How Do Companies Organize Nascent Markets? The BlaBlaCar Case in the Inter-City Shared Mobility Market. Technol. Forecast. Soc. Chang. 2019, 144, 270-281. [CrossRef]

4. Park, H.; Joyner Armstrong, C.M. Is Money the Biggest Driver? Uncovering Motives for Engaging in Online Collaborative Consumption Retail Models for Apparel. J. Retail. Consum. Serv. 2019, 51, 42-50. [CrossRef]

5. Botsman, R.; Rogers, R. What's Mine Is Yours: The Rise of Collaborative Consumption; Harperbusiness: New York, NY, USA, 2010; p. 24.

6. Fraanje, W.; Spaargaren, G. What Future for Collaborative Consumption? A Practice Theoretical Account. J. Clean. Prod. 2019, 208, 499-508. [CrossRef]

7. Lu, Y.; Zhao, L.; Wang, B. From Virtual Community Members to C2C E-Commerce Buyers: Trust in Virtual Communities and Its Effect on Consumers' Purchase Intention. Electron. Commer. Res. Appl. 2010, 9, 346-360. [CrossRef]

8. Busalim, A.H.; Ghabban, F.; Hussin, A.R.C. Customer Engagement Behaviour on Social Commerce Platforms: An Empirical Study. Technol. Soc. 2021, 64, 101437. [CrossRef]

9. Mikalef, P.; Giannakos, M.; Pateli, A. Shopping and Word-of-Mouth Intentions on Social Media. J. Theor. Appl. Electron. Commer. Res. 2013, 8, 17-34. [CrossRef]

10. Hennig-Thurau, T.; Gwinner, K.P.; Walsh, G.; Gremler, D.D. Electronic Word-of-Mouth via Consumer-Opinion Platforms: What Motivates Consumers to Articulate Themselves on the Internet? J. Interact. Mark. 2004, 18, 38-52. [CrossRef]

11. Zulkiffli, W.F.W.; Hong, L.M.; Ramlee, S.I.F. The Effectiveness Of Electronic Word-Of-Mouth (Ewom) On Consumer Purchase Intention Among Generation-Y. 9. Int. J. Account. 2017, 2, 18-26.

12. Tien, D.H.; Amaya Rivas, A.A.; Liao, Y.-K. Examining the Influence of Customer-to-Customer Electronic Word-of-Mouth on Purchase Intention in Social Networking Sites. Asia Pac. Manag. Rev. 2019, 24, 238-249. [CrossRef]

13. Kuo, H.-C.; Nakhata, C. The Impact of Electronic Word-of-Mouth on Customer Satisfaction. J. Mark. Theory Pract. 2019, 27, 331-348. [CrossRef]

14. Pyle, M.A.; Smith, A.N.; Chevtchouk, Y. In EWOM We Trust: Using Naïve Theories to Understand Consumer Trust in a Complex EWOM Marketspace. J. Bus. Res. 2021, 122, 145-158. [CrossRef]

15. Kwak, J.; Zhang, Y.; Yu, J. Legitimacy Building and E-Commerce Platform Development in China: The Experience of Alibaba. Technol. Forecast. Soc. Chang. 2019, 139, 115-124. [CrossRef]

16. Joo, J. Roles of the Buyer's Trust in Seller in Posted-Price Model of Consumer to Consumer E-Commerce. J. Theor. Appl. Electron. Commer. Res. 2015, 10, 30-44. [CrossRef]

17. Ismagilova, E.; Dwivedi, Y.K.; Slade, E.; Williams, M. Electronic Word of Mouth (EWOM) in the Marketing Context: A State of the Art Analysis and Future Directions; SpringerBriefs in Business; Springer International Publishing: Berlin/Heidelberg, Germany, 2017; ISBN 978-3-319-52458-0.

18. Peltier, J.W.; Dahl, A.J.; Swan, E.L. Digital Information Flows across a B2C/C2C Continuum and Technological Innovations in Service Ecosystems: A Service-Dominant Logic Perspective. J. Bus. Res. 2020, 121, 724-734. [CrossRef] 
19. Khwaja, M.G.; Mahmood, S.; Zaman, U. Examining the Effects of EWOM, Trust Inclination, and Information Adoption on Purchase Intentions in an Accelerated Digital Marketing Context. Information 2020, 11, 478. [CrossRef]

20. Xu, Q. Should I Trust Him? The Effects of Reviewer Profile Characteristics on EWOM Credibility. Comput. Hum. Behav. 2014, 33, 136-144. [CrossRef]

21. Verma, S.; Yadav, N. Past, Present, and Future of Electronic Word of Mouth (EWOM). J. Interact. Mark. 2021, 53, 111-128. [CrossRef]

22. Juniper Research: Sharing Economy Revenues to Double by 2022, Reaching Over $\$ 40$ Billion. Available online: https: / / www.businesswire.com/news/home/20170724005477/en/Juniper-Research-Sharing-Economy-Revenues-to-Double-by2022-Reaching-Over-40-billion (accessed on 26 December 2020).

23. Ianole-Călin, R.; Francioni, B.; Masili, G.; Druică, E.; Goschin, Z. A Cross-Cultural Analysis of How Individualism and Collectivism Impact Collaborative Consumption. Resour. Conserv. Recycl. 2020, 157, 104762. [CrossRef]

24. Zhao, J.-D.; Huang, J.-S.; Su, S. The Effects of Trust on Consumers' Continuous Purchase Intentions in C2C Social Commerce: A Trust Transfer Perspective. J. Retail. Consum. Serv. 2019, 50, 42-49. [CrossRef]

25. Sussman, S.W.; Siegal, W.S. Informational Influence in Organizations: An Integrated Approach to Knowledge Adoption. Inf. Syst. Res. 2003, 14, 47-65. [CrossRef]

26. Davis, F.D. Perceived Usefulness, Perceived Ease of Use, and User Acceptance of Information Technology. Mis. Q. 1989, 13, 319-340. [CrossRef]

27. Shih, H.; Lai, K.; Cheng, T.C.E. Informational and Relational Influences on Electronic Word of Mouth: An Empirical Study of an Online Consumer Discussion Forum. Int. J. Electron. Commer. 2013, 17, 137-166. [CrossRef]

28. Chatterjee, S.; Goyal, D.; Prakash, A.; Sharma, J. Exploring Healthcare/Health-Product Ecommerce Satisfaction: A Text Mining and Machine Learning Application. J. Bus. Res. 2020. [CrossRef]

29. Tan, J.; Tyler, K.; Manica, A. Business-to-Business Adoption of ECommerce in China. Inf. Manag. 2007, 44, 332-351. [CrossRef]

30. Huang, G.Q.; de Koster, R.; Yu, Y. Editorial: Online-to-Offline Ecommerce Operations Management (EOM). Transp. Res. Part E Logist. Transp. Rev. 2020, 138, 101920. [CrossRef]

31. Liu, H.; Jayawardhena, C.; Osburg, V.-S.; Yoganathan, V.; Cartwright, S. Social Sharing of Consumption Emotion in Electronic Word of Mouth (EWOM): A Cross-Media Perspective. J. Bus. Res. 2021, 132, 208-220. [CrossRef]

32. Ismagilova, E.; Dwivedi, Y.K.; Slade, E. Perceived Helpfulness of EWOM: Emotions, Fairness and Rationality. J. Retail. Consum. Serv. 2020, 53, 101748. [CrossRef]

33. Bhandari, M.; Rodgers, S.; Pan, P.-L. Brand Feedback to Negative EWOM Messages: Effects of Stability and Controllability of Problem Causes on Brand Attitudes and Purchase Intentions. Telemat. Inform. 2021, 58, 101522. [CrossRef]

34. Le, D.; Pratt, M.; Wang, Y.; Scott, N.; Lohmann, G. How to Win the Consumer's Heart? Exploring Appraisal Determinants of Consumer Pre-Consumption Emotions. Int. J. Hosp. Manag. 2020, 88, 102542. [CrossRef]

35. Dwidienawati, D.; Tjahjana, D.; Abdinagoro, S.B.; Gandasari, D. Munawaroh Customer Review or Influencer Endorsement: Which One Influences Purchase Intention More? Heliyon 2020, 6, e05543. [CrossRef]

36. Naujoks, A.; Benkenstein, M. Who Is behind the Message? The Power of Expert Reviews on EWOM Platforms. Electron. Commer. Res. Appl. 2020, 44, 101015. [CrossRef]

37. Pang, H. Identifying Associations between Mobile Social Media Users' Perceived Values, Attitude, Satisfaction, and EWOM Engagement: The Moderating Role of Affective Factors. Telemat. Inform. 2021, 59, 101561. [CrossRef]

38. Wang, J.-J.; Wang, L.-Y.; Wang, M.-M. Understanding the Effects of EWOM Social Ties on Purchase Intentions: A Moderated Mediation Investigation. Electron. Commer. Res. Appl. 2018, 28, 54-62. [CrossRef]

39. Erkan, I.; Evans, C. The Influence of EWOM in Social Media on Consumers' Purchase Intentions: An Extended Approach to Information Adoption. Comput. Hum. Behav. 2016, 61, 47-55. [CrossRef]

40. See-To, E.W.K.; Ho, K.K.W. Value Co-Creation and Purchase Intention in Social Network Sites: The Role of Electronic Word-ofMouth and Trust-A Theoretical Analysis. Comput. Hum. Behav. 2014, 31, 182-189. [CrossRef]

41. Cheng, G.; Cherian, J.; Sial, M.S.; Mentel, G.; Wan, P.; Álvarez-Otero, S.; Saleem, U. The Relationship between CSR Communication on Social Media, Purchase Intention, and E-WOM in the Banking Sector of an Emerging Economy. J. Theor. Appl. Electron. Commer. Res. 2021, 16, 1025-1041. [CrossRef]

42. Jacobsen, S. Why Did I Buy This? The Effect of WOM and Online Reviews on Post Purchase Attribution for Product Outcomes. J. Res. Interact. Mark. 2018, 12, 370-395. [CrossRef]

43. Septianto, F.; Chiew, T.M. The Effects of Different, Discrete Positive Emotions on Electronic Word-of-Mouth. J. Retail. Consum. Serv. 2018, 44, 1-10. [CrossRef]

44. Nadarajan, G.; Bojei, J.; Khalid, H. The Study on Negative EWOM and Its Relationship to Consumer's Intention to Switch Mobile Service Provider. Procedia Comput. Sci. 2017, 124, 388-396. [CrossRef]

45. Cummins, S.; Peltier, J.W.; Schibrowsky, J.A.; Nill, A. Consumer Behavior in the Online Context. J. Res. Interact. Mark. 2014, 8 , 169-202. [CrossRef]

46. Dwivedi, Y.K.; Ismagilova, E.; Hughes, D.L.; Carlson, J.; Filieri, R.; Jacobson, J.; Jain, V.; Karjaluoto, H.; Kefi, H.; Krishen, A.S.; et al. Setting the Future of Digital and Social Media Marketing Research: Perspectives and Research Propositions. Int. J. Inf. Manag. 2020, 102168. [CrossRef] 
47. Gruen, T.W.; Osmonbekov, T.; Czaplewski, A.J. EWOM: The Impact of Customer-to-Customer Online Know-How Exchange on Customer Value and Loyalty. J. Bus. Res. 2006, 59, 449-456. [CrossRef]

48. Lin, G.T.R.; Sun, C. Factors Influencing Satisfaction and Loyalty in Online Shopping: An Integrated Model. Online Inf. Rev. 2009, 33, 458-475. [CrossRef]

49. Nguyen, T.T.N. Developing and Validating Five-Construct Model of Customer Satisfaction in Beauty and Cosmetic E-Commerce. Heliyon 2020, 6, e04887. [CrossRef]

50. Molla, A.; Licker, P. E-Commerce Systems Success: An Attempt to Extend and Respecify the Delone and MaClean Model of IS Success. J. Electron. Commer. Res. 2001, 2, 131-141.

51. Nisar, T.M.; Prabhakar, G. What Factors Determine E-Satisfaction and Consumer Spending in e-Commerce Retailing? J. Retail. Consum. Serv. 2017, 39, 135-144. [CrossRef]

52. Attar, R.W.; Shanmugam, M.; Hajli, N. Investigating the Antecedents of E-Commerce Satisfaction in Social Commerce Context. Br. Food J. 2020, 123, 849-868. [CrossRef]

53. Wang, Y. Information Adoption Model, a Review of the Literature. J. Econ. Bus. Manag. 2016, 4, 618-622. [CrossRef]

54. Fishbein, M.; Ajzen, I. Belief, Attitude, Intention, and Behavior: An Introduction to Theory and Research; Addison-Wesley Pub. Co.: Reading, MA, USA, 1975; ISBN 978-0-201-02089-2.

55. Tseng, S.-Y.; Wang, C.-N. Perceived Risk Influence on Dual-Route Information Adoption Processes on Travel Websites. J. Bus. Res. 2016, 69, 2289-2296. [CrossRef]

56. Petty, R.E.; Cacioppo, J.T. The Elaboration Likelihood Model of Persuasion. In Advances in Experimental Social Psychology; Berkowitz, L., Ed.; Academic Press: Cambridge, MA, USA, 1986; Volume 19, pp. 123-205.

57. Goh, D.; Chi, J. Central or Peripheral? Information Elaboration Cues on Childhood Vaccination in an Online Parenting Forum. Comput. Hum. Behav. 2017, 69, 181-188. [CrossRef]

58. El Hedhli, K.; Zourrig, H.; Becheur, I. Celebrity Endorsements: Investigating the Interactive Effects of Internalization, Identification and Product Type on Consumers' Attitudes and Intentions. J. Retail. Consum. Serv. 2021, 58, 102260. [CrossRef]

59. Cyr, D.; Head, M.; Lim, E.; Stibe, A. Using the Elaboration Likelihood Model to Examine Online Persuasion through Website Design. Inf. Manag. 2018, 55, 807-821. [CrossRef]

60. Cheung Christy, M.K.; Lee Matthew, K.O. Rabjohn Neil The Impact of Electronic Word-of-mouth: The Adoption of Online Opinions in Online Customer Communities. Internet Res. 2008, 18, 229-247. [CrossRef]

61. Li, C.-Y. Persuasive Messages on Information System Acceptance: A Theoretical Extension of Elaboration Likelihood Model and Social Influence Theory. Comput. Hum. Behav. 2013, 29, 264-275. [CrossRef]

62. Zhang, K.Z.K.; Zhao, S.J.; Cheung, C.M.K.; Lee, M.K.O. Examining the Influence of Online Reviews on Consumers' DecisionMaking: A Heuristic-Systematic Model. Decis. Support Syst. 2014, 67, 78-89. [CrossRef]

63. Hendijani Fard, M.; Marvi, R. Viral Marketing and Purchase Intentions of Mobile Applications Users. Int. J. Emerg. Mark. 2019, 15, 287-301. [CrossRef]

64. Hussain, S.; Guangju, W.; Jafar, R.M.S.; Ilyas, Z.; Mustafa, G.; Jianzhou, Y. Consumers' Online Information Adoption Behavior: Motives and Antecedents of Electronic Word of Mouth Communications. Comput. Hum. Behav. 2018, 80, 22-32. [CrossRef]

65. Chen, X.; Huang, Q.; Davison, R.M. The Role of Website Quality and Social Capital in Building Buyers' Loyalty. Int. J. Inf. Manag. 2017, 37, 1563-1574. [CrossRef]

66. Anastasiei, B.; Dospinescu, N. Facebook Advertising: Relationship Between Types Of Message, Brand Attitude And Perceived Buying Risk. Ann. Univ. Craiova 2017, 1, 18-26.

67. Karamchandani, A.; Srivastava, S.K.; Srivastava, R.K. Perception-Based Model for Analyzing the Impact of Enterprise Blockchain Adoption on SCM in the Indian Service Industry. Int. J. Inf. Manag. 2020, 52, 102019. [CrossRef]

68. Marimon, F.; Llach, J.; Alonso-Almeida, M.; Mas-Machuca, M. CC-Qual: A Holistic Scale to Assess Customer Perceptions of Service Quality of Collaborative Consumption Services. Int. J. Inf. Manag. 2019, 49, 130-141. [CrossRef]

69. Parasuraman, A.; Zeithaml, V.A.; Malhotra, A. E-S-QUAL: A Multiple-Item Scale for Assessing Electronic Service Quality. Available online: https:/ /journals.sagepub.com/doi/10.1177/1094670504271156 (accessed on 26 December 2020).

70. Basili, M.; Rossi, M.A. Platform-Mediated Reputation Systems in the Sharing Economy and Incentives to Provide Service Quality: The Case of Ridesharing Services. Electron. Commer. Res. Appl. 2020, 39, 100835. [CrossRef]

71. Zuo, W.; Zhu, W.; Chen, S.; He, X. A 2020 Perspective on "Service Quality Management of Online Car-Hailing Based on PCN in the Sharing Economy". Electron. Commer. Res. Appl. 2020, 40, 100941. [CrossRef]

72. Marín, G.J.; Marcos, P.S.; Medina, I.G.; Coelho, P.M.F. How Big Data Collected Via Point of Sale Devices in Textile Stores in Spain Resulted in Effective Online Advertising Targeting. Int. J. Interact. Mob. Technol. 2020, 14, 65-77. [CrossRef]

73. Tandon, A.; Aakash, A.; Aggarwal, A.G. Impact of EWOM, Website Quality, and Product Satisfaction on Customer Satisfaction and Repurchase Intention: Moderating Role of Shipping and Handling. Int. J. Syst. Assur. Eng. Manag. 2020, 11, 349-356. [CrossRef]

74. Jones, K.; Leonard, L.N.K. Consumer-to-Consumer Electronic Commerce: A Distinct Research Stream. J. Electron. Commer. Organ. 2007, 5, 39-54. [CrossRef]

75. Leeraphong, A.; Mahatanankoon, P.; Papasratorn, B. Evaluating Electronic Service Quality for C2C Social Commerce in Thailand: A Pilot Study. In Proceedings of the 2016 Eleventh International Conference on Digital Information Management (ICDIM), Porto, Portugal, 19-21 September 2016; pp. 191-196. 
76. Bauer, H.H.; Falk, T.; Hammerschmidt, M. ETransQual: A Transaction Process-Based Approach for Capturing Service Quality in Online Shopping. J. Bus. Res. 2006, 59, 866-875. [CrossRef]

77. Wu, K.; Vassileva, J.; Noorian, Z.; Zhao, Y. How Do You Feel When You See a List of Prices? The Interplay among Price Dispersion, Perceived Risk and Initial Trust in Chinese C2C Market. J. Retail. Consum. Serv. 2015, 25, 36-46. [CrossRef]

78. López, M.; Sicilia, M. Determinants of E-WOM Influence: The Role of Consumers' Internet Experience. J. Theor. Appl. Electron. Commer. Res. 2014, 9, 28-43. [CrossRef]

79. Serra-Cantallops, A.; Ramon-Cardona, J.; Salvi, F. The Impact of Positive Emotional Experiences on EWOM Generation and Loyalty. Span. J. Mark. Esic 2018, 22, 142-162. [CrossRef]

80. Luo, N.; Wang, Y.; Zhang, M.; Niu, T.; Tu, J. Integrating Community and E-Commerce to Build a Trusted Online Second-Hand Platform: Based on the Perspective of Social Capital. Technol. Forecast. Soc. Chang. 2020, 153, 119913. [CrossRef]

81. Cheng, X.; Fu, S.; de Vreede, G.-J. A Mixed Method Investigation of Sharing Economy Driven Car-Hailing Services: Online and Offline Perspectives. Int. J. Inf. Manag. 2018, 41, 57-64. [CrossRef]

82. Zhu, D.H.; Chang, Y.P.; Luo, J.J. Understanding the Influence of C2C Communication on Purchase Decision in Online Communities from a Perspective of Information Adoption Model. Telemat. Inform. 2016, 33, 8-16. [CrossRef]

83. Rhee, C.E.; Choi, J. Effects of Personalization and Social Role in Voice Shopping: An Experimental Study on Product Recommendation by a Conversational Voice Agent. Comput. Hum. Behav. 2020, 109, 106359. [CrossRef]

84. Yap, K.B.; Soetarto, B.; Sweeney, J.C. The Relationship between Electronic Word-of-Mouth Motivations and Message Characteristics: The Sender's Perspective. Australas. Mark. J. 2013, 21, 66-74. [CrossRef]

85. Sokolova, K.; Kefi, H. Instagram and YouTube Bloggers Promote It, Why Should I Buy? How Credibility and Parasocial Interaction Influence Purchase Intentions. J. Retail. Consum. Serv. 2020, 53. [CrossRef]

86. John, S.P.; De'Villiers, R. Elaboration of Marketing Communication through Visual Media: An Empirical Analysis. J. Retail. Consum. Serv. 2020, 54, 102052. [CrossRef]

87. Li, C. The Placebo Effect in Web-Based Personalization. Telemat. Inform. 2019, 44, 101267. [CrossRef]

88. Chang, Y.-T.; Yu, H.; Lu, H.-P. Persuasive Messages, Popularity Cohesion, and Message Diffusion in Social Media Marketing. J. Bus. Res. 2015, 68, 777-782. [CrossRef]

89. Chang, H.H.; Lu, Y.-Y.; Lin, S.C. An Elaboration Likelihood Model of Consumer Respond Action to Facebook Second-Hand Marketplace: Impulsiveness as a Moderator. Inf. Manag. 2020, 57, 103171. [CrossRef]

90. Ham, J.; Lee, K.; Kim, T.; Koo, C. Subjective Perception Patterns of Online Reviews: A Comparison of Utilitarian and Hedonic Values. Inf. Process. Manag. 2019, 56, 1439-1456. [CrossRef]

91. Jin, X.-L.; Cheung, C.M.K.; Lee, M.K.O.; Chen, H.-P. How to Keep Members Using the Information in a Computer-Supported Social Network. Comput. Hum. Behav. 2009, 25, 1172-1181. [CrossRef]

92. Ren, G.; Hong, T. Examining the Relationship between Specific Negative Emotions and the Perceived Helpfulness of Online Reviews. Inf. Process. Manag. 2019, 56, 1425-1438. [CrossRef]

93. Gunawan, D.D.; Huarng, K.-H. Viral Effects of Social Network and Media on Consumers' Purchase Intention. J. Bus. Res. 2015, 68, 2237-2241. [CrossRef]

94. Ruiz-Mafe, C.; Chatzipanagiotou, K.; Curras-Perez, R. The Role of Emotions and Conflicting Online Reviews on Consumers' Purchase Intentions. J. Bus. Res. 2018, 89, 336-344. [CrossRef]

95. Siddiqui, M.S.; Siddiqui, U.A.; Khan, M.A.; Alkandi, I.G.; Saxena, A.K.; Siddiqui, J.H. Creating Electronic Word of Mouth Credibility through Social Networking Sites and Determining Its Impact on Brand Image and Online Purchase Intentions in India. J. Theor. Appl. Electron. Commer. Res. 2021, 16, 1008-1024. [CrossRef]

96. Cheung, C.M.K.; Thadani, D.R. The Impact of Electronic Word-of-Mouth Communication: A Literature Analysis and Integrative Model. Decis. Support Syst. 2012, 54, 461-470. [CrossRef]

97. Park, M.-S.; Shin, J.-K.; Ju, Y. Attachment Styles and Electronic Word of Mouth (e-WOM) Adoption on Social Networking Sites. J. Bus. Res. 2019, 99, 398-404. [CrossRef]

98. Abubakar, A.M.; Ilkan, M.; Meshall Al-Tal, R.; Eluwole, K.K. EWOM, Revisit Intention, Destination Trust and Gender. J. Hosp. Tour. Manag. 2017, 31, 220-227. [CrossRef]

99. Anastasiei, B.; Dospinescu, N. Paid Product Reviews in Social Media-Are They Effective? In Proceedings of the 34th International Business Information Management Association Conference, Vision 2025: Education Excellence and Management of Innovations through Sustainable Economic Competitive Advantage, Madrid, Spain, 13-14 November 2019.

100. Zhao, Y.; Ni, Q.; Zhou, R. What Factors Influence the Mobile Health Service Adoption? A Meta-Analysis and the Moderating Role of Age. Int. J. Inf. Manag. 2018, 43, 342-350. [CrossRef]

101. Li, Y.; Mou, J.; Ye, L.; Long, J.; Huang, W. An Empirical Investigation of the Utilitarian, Social Benefits in LBS Information Disclosure-The Moderating Effect of the Gender Based Social Role Theory. Int. J. Inf. Manag. 2021, 56, 102243. [CrossRef]

102. Aboobucker, I.; Bao, Y. What Obstruct Customer Acceptance of Internet Banking? Security and Privacy, Risk, Trust and Website Usability and the Role of Moderators. J. High Technol. Manag. Res. 2018, 29, 109-123. [CrossRef]

103. Martins, C.; Oliveira, T.; Popovič, A. Understanding the Internet Banking Adoption: A Unified Theory of Acceptance and Use of Technology and Perceived Risk Application. Int. J. Inf. Manag. 2014, 34, 1-13. [CrossRef]

104. Gnambs, T. The Development of Gender Differences in Information and Communication Technology (ICT) Literacy in Middle Adolescence. Comput. Hum. Behav. 2021, 114, 106533. [CrossRef] 
105. González, E.M.; Meyer, J.-H.; Paz Toldos, M. What Women Want? How Contextual Product Displays Influence Women's Online Shopping Behavior. J. Bus. Res. 2021, 123, 625-641. [CrossRef]

106. Tsourela, M.; Roumeliotis, M. The Moderating Role of Technology Readiness, Gender, and Sex in Consumer Acceptance and Actual Use of Technology-Based Services. J. High Technol. Manag. Res. 2015, 26, 124-136. [CrossRef]

107. Shehryar, O. The Effect of Buyer's Gender, Risk-proneness, and Time Remaining in an Internet Auction on the Decision to Bid or Buy-it-now. J. Prod. Brand Manag. 2008, 17, 356-365. [CrossRef]

108. Lim, Y.S.; Heng, P.C.; Ng, T.H.; Cheah, C.S. Customers' Online Website Satisfaction in Online Apparel Purchase: A Study of Generation $\mathrm{Y}$ in Malaysia. Asia Pac. Manag. Rev. 2016, 21, 74-78. [CrossRef]

109. Hsu, M.-H.; Chang, C.-M.; Chuang, L.-W. Understanding the Determinants of Online Repeat Purchase Intention and Moderating Role of Habit: The Case of Online Group-Buying in Taiwan. Int. J. Inf. Manag. 2015, 35, 45-56. [CrossRef]

110. Kline, R.B. Principles and Practice of Structural Equation Modeling: Fourth Edition; Guilford Publications: New York, NY, USA, 2015.

111. Fornell, C.; Larcker, D.F. Evaluating Structural Equation Models with Unobservable Variables and Measurement Error. J. Mark. Res. 1981, 18, 39-50. [CrossRef]

112. Henseler, J.; Ringle, C.M.; Sarstedt, M. A New Criterion for Assessing Discriminant Validity in Variance-Based Structural Equation Modeling. J. Acad. Mark. Sci. 2015, 43, 115-135. [CrossRef]

113. Hair, J.F.; Howard, M.C.; Nitzl, C. Assessing Measurement Model Quality in PLS-SEM Using Confirmatory Composite Analysis. J. Bus. Res. 2020, 109, 101-110. [CrossRef]

114. Kock, N. Common Method Bias in PLS-SEM: A Full Collinearity Assessment Approach. Int. J. E Collab. 2015. [CrossRef]

115. Texas A\&M International University; Kock, N.; Lynn, G.; Stevens Institute of Technology. Lateral Collinearity and Misleading Results in Variance-Based SEM: An Illustration and Recommendations. J. Assoc. Inf. Syst. 2012, 13, 546-580. [CrossRef]

116. Dospinescu, O.; Percă-Robu, A.E. The Analysis of E-Commerce Sites with Eye-Tracking Technologies. Brain. Broad Res. Artif. Intell. Neurosci. 2017, 8, 85-100.

117. Joo, Y.G.; Sohn, S.Y. Structural Equation Model for Effective CRM of Digital Content Industry. Expert Syst. Appl. 2008, 34, 63-71. [CrossRef] 